\title{
THE RELATIONSHIP BETWEEN CREATIVITY, IDENTITY, PLACE, AND COMMUNITY RESILIENCE: THE RENAISSANCE OF CLARKSDALE, MISSISSIPPI, UNITED STATES
}

\author{
Terrie WADDELL \\ Department of Creative Arts and English, School of Humanities and Social Sciences, \\ La Trobe University, Plenty Road, Bundoora, Melbourne, Victoria, 3086, Australia
}

Received 15 June 2020; accepted 16 December 2020

\begin{abstract}
This paper examines the relationship between creativity, identity, and place for the small economically challenged Delta City, Mississippi of Clarksdale, United States, a once prosperous manufacturing and farming community. Promoted as the Delta's epicenter of blues music, over the last twenty years key business stakeholders in the city's renaissance have been committed to developing local and international awareness of Clarksdale's historic architecture, culture and blues heritage. It was not until 2008 when economist and town planner John C. Henshall formulated the Downtown Clarksdale Action Plan for Economic Revitalization that the city secured a comprehensive guide to growth. The plan was designed to support downtown infrastructure and tourism through a creatively based strategy, dependent on the tourism potential of blues performances and the imaginative efforts of those invested in the ongoing renewal project. Drawing on incentives aligned with the plan's objectives, and seven semi-structured interviews with local entrepreneurs and revitalization participants, this paper examines the connection between collaborative creativity, collective identity, connection to place, and community resilience.
\end{abstract}

Keywords: blues music, Clarksdale, community identity, creativity, place, resilience.

\section{Introduction}

The expression of creativity and the artifacts, initiatives and industries it produces, are able to influence economic growth and a sense of belonging for regional communities facing difficult, sometimes overwhelming challenges. The uniqueness of place and its historical relationship to artistic practices, contributes significantly to the development of businesses and more grass roots opportunities that pay homage to the past while building on its legacy to inspire collective identity. This paper draws on the single case study of Clarksdale as an example of how incremental recovery is possible through the creative initiatives of a small inland town struggling with population decline and competition from affluent metropolitan centres for commercial resources. Through the implementation of a downtown revitalization scheme -

${ }^{\star}$ Corresponding author. E-mail: t.waddell@latrobe.edu.au

Copyright (c) 2021 The Author(s). Published by Vilnius Gediminas Technical University

This is an Open Access article distributed under the terms of the Creative Commons Attribution License (http://creativecommons. org/licenses/by/4.0/), which permits unrestricted use, distribution, and reproduction in any medium, provided the original author and source are credited. 
Downtown Clarksdale Action Plan for Economic Revitalization - initiated by key municipal stakeholders and designed by economist, town planner and former director of Essential Economics (1997-2018), Henshall (2008), Clarksdale has built on its blues music and related artistic and architectural heritage to grow its marketplace value as a niche tourist destination.

This study draws on seven semi-structured interviews with entrepreneurs and revitalization participants currently involved in Clarksdale's development. Those interviewed in Clarksdale and Melbourne, Australia (2018 and 2020) were selected for their innovative involvement in Clarksdale's creative industries: the majority were also familiar with Henshall's renewal initiatives. The respondents, who wished to be unnamed, will be referred to as R1-R7. All exchanges focused on open-ended questions relating to practical business operations, the perceived value of entrepreneurship, practicalities of initiating and/or financing investments, and thoughts on active or potential community engagement. An emphasis on mobilizing creativity, identity, and the uniqueness of place as a response to challenging socio-economic circumstances, emerged as central themes and consequently formed the framework of this article.

Formulated in consultation with key revitalization stakeholders, the Downtown Clarksdale Action Plan for Economic Revitalization was inspired by Clarksdale’s 2000 "General Development Plan”, updated in 2003-2007 (Henshall, 2008, p. 31). Henshall (2012, p. 41) drew on "land use and floorspace surveys of downtown businesses, and assessments of retail and tourism business activities", while also interviewing fifty residents, members of local organizations, and tourists taking part in Clarksdale's celebrated Juke Joint Festival which provides a third of the city's annual revenue. His key objectives focused on tourism and the city's potential to restore buildings for investment, develop businesses, create housing, support community education, and foster creativity. Although the plan has been used as a guide for revitalization, it would be misleading to imply that the 110 page document was adopted verbatim.

\section{A brief history of Clarksdale's creative heritage}

The Mississippi Delta, Mississippi is one of the most socio-economically challenged regions in the United States (US), with Clarksdale's wider Coahoma County designated as economically "distressed" (Bryant, 2016, p. 5). Steeped in plantation history, Clarksdale sits in the Northern area of the Mississippi Delta, and incorporates Eastern portions of Louisiana and Arkansas. Commercialized as the epicenter of Delta blues, the town was born from a 19th century culture of racial subjugation where music afforded African American and impoverished white communities emotional catharsis (Pratt, 1986; also see documentary film ReMastered: Devil at the Crossroads (director Brian Oaks, 2019)). Despite the rich historical sites and art forms/artists - famously Clarksdale playwright Tennessee Williams (1911-1983), and Nobel laureate, author William Faulkner (1897-1962) of Oxford, Lafayette County, Mississippi - the growth of tourism in the Delta City dominantly focuses on music festival culture and the Mississippi Blues Trail (MBT) to capitalize on the area's cultivated identity as the homeland of American blues music (Meikle, 2016; King, 2004). 
Apart from more established tributes to noted blues music and musicians, like the B.B. King Museum and the Grammy Museum in Cleveland, Mississippi, the Delta juke joints have become significant features of the MBT. These venues, repurposed buildings with interior upcycling as a mode of décor that utilizes salvaged local and historical paraphernalia, initially served African-American musicians and patrons. The current Juke Joint Festival, managed from Clarksdale and co-founded in 2004 by spokesman Roger Stolle, is now in its seventeenth year. The event drew an estimated 7000 patrons in 2018 from fifty-three Delta counties, forty-six North American States and twenty-eight countries and combines with seventeen Clarksdale arts festivals, attracting 70000 locals and tourists annually (Henshall, 2019; Stolle, 2019). Clarksdale juke joints, including Red's Lounge originally Lavene Music Centre (c. 1916), Ground Zero Blues Club (c. 1905), and the Shack Up Inn (c. 1852) converted from cotton gin barns and Hobson Plantation shacks, currently hosts local tourists and returning-visiting musicians from the wider Delta community (MDAH. HRI Historic District Profile. District Properties, 2020). Legendary juke joints examples include Po' Monkey's, initially operating under segregation from 1961-2016 (see Jacks, 2019), J.J.s Juke Joint, a former segregated café and grocery store, and nearby Shelby's, North Carolina (US) Do Drop Inn. In her work on the history and architecture of these venues, Nardone (2003, p. 174) notes that "Juke Joints are essential pieces of the cultural landscape because of the fusion of the physical and the metaphorical, offering a wider lens for understanding the Delta".

Clarksdale and the Delta's current declining population and household income status has fallen from past economic prosperity during the segregation (Jim Crow) period of the 1950s-1970s, due to agricultural "mechanization and investments in capital", apropos land acquisition by larger companies in a growing globalized economy (Meikle, 2016, p. 131; U.S. Census Bureau, 2019; Town Charts, 2019). For Southern rural communities the obvious factors impacting development, as Beaulieu (2019) observed during Clarksdale's economic decline, include the loss of manufacturing industries, economic productivity, educational support, and healthcare. With its segregated community, R3 describes how Clarksdale was once

"shoulder to shoulder for blocks on a Saturday night, with car manufacturers and dealers, theatres and clothing stores lining the street, with African Americans shopping in Yazoo Street and white residents shopping in Delta Street".

Interlinking creativity, identity and place with economic buoyancy and the kind of flexibility key to resilience, R3 adds that the current popular appeal of Clarksdale's blues heritage, inspired entrepreneurs to focus on "the potential of that market" while also supporting a variety of arts initiatives:

"the regular Barefoot Film Workshops, the annual scholarships provided to young Delta musicians by the world-renown Boston-based Berklee School of Music, the Delta Writers Association, the Clarksdale Film Festival" (Henshall, 2012, p. 33, see also 2019).

\section{The individual, collective and interdisciplinary nature of creativity}

The concept of creativity is broad, encompassing not only artists and their output, but also the skills of those facilitating and contributing to a particular creative vision. Henshall (2019, p. 119) describes a variety of participants actively involved in downtown revitalization as 
“creative people", a concept aligned with Landry's (2008) “creative city" model that suggests successful cities are born of visionary and creative contributors working toward a shared vision. The actual concept of creativity though is illusive - classically defined in the 1950s as a mixture of originality and value, where the behaviour demonstrated, or the artifact produced, was imagined to be unique and useful (Runco \& Jaeger, 2012; Barron, 1955; Stein, 1953). Runco's and Jaeger's (2012, p. 93) review of the definition also touches on the outdated 19th century conflation of "creativity and genius". Hennessey and Amabile (2010, p. 571) discuss a lack of disciplinary collaboration in definitions of the term and argue that any advancement in creativity studies must take into consideration an understanding of creativity as "a system of interrelated forces operating at multiple levels, often requiring interdisciplinary investigation". They conclude that creativity cannot be measured through any single theoretical paradigm but should be considered alongside the uneven field of research into creativity that enfolds, for instance, sociology, science and psychology. The expression of creativity not only involves a range of disciplines, skills and processes in producing outputs, but the combined social and economically informed effort required for their production.

Glăveanu (2010, p. 90) identifies three paradigms that have influenced psychological understandings of creativity: "the [consciously gendered] He-paradigm" that locates "creativity inside "unique' individuals"; "the I-paradigm" where creativity is found "inside each and every individual taken separately"; and the "We-paradigm" that considers "more systemic approaches of creativity, comprehensive views that incorporate multiple levels, from individuals and interpersonal interactions, to groups and cultures". When applying the concept of creativity to groups and communities, it is important to appreciate the role of the social in this dynamic. Through this inner/outer interaction discussed in the following section, creativity becomes a collaborative process leading to shared outcomes and the potential for an evolving cultural identity. In working with leading "creative people" in the town, including a portion of the respondents for this paper. Henshall demonstrates that creativity is a process of embracing artistic practice, commerce, urban planning and the interpersonal intricacies of collaboration (2019). This emphasis on the importance of creativity leads to the central question underpinning Clarksdale's communal effort - or "distributed creativity" for Sawyer and DeZutter (2009, p. 82) - how does such arts driven teamwork contribute to community resilience? As R2 notes, "when you run out of money you get creative, you get into survival and you start pulling on talents and creativity that you don't know are here".

For those observing the shifting focus in resilience away from its initial ecological application, to communities faced with sudden and incremental challenges, the general consensus is that resilience is characterized by the ability to manage change and insecurity while also developing immediate and long-term survival strategies (Magis, 2010; Berkes \& Ross, 2013). For Magis, resilience predicts a group's capacity to sustain its response to stressful, often unpredictable, situations by collectively, innovatively and strategically planning ahead and deploying shared resources. Clarksdale's Downtown Clarksdale Action Plan for Economic Revitalization and the downtown community's engagement with its vision, aligns with this thinking, as does the value of its new, actively change-making/entrepreneurial residents: as Magis (2010, p. 403) writes, "Communities are inhabited by successive waves of people [...] utilized for different purposes in different time periods. The level and kinds of resources 
invested in them change". Drawing on mental health and psychological models of resilience, while acknowledging the necessity of readying for change, Berkes and Ross (2013, p. 10) understand community resilience in terms of fostering "strengths, rather than [...] overcoming deficits", through social networks and leaders able to effect inter-personal problem-solving communication and positively guide momentum. As discussed below, Clarksdale's leadership in revitalization for the benefit of downtown and the wider community, are clearly concentrated around a desire to creatively build resilience.

\title{
3. Creativity and identity
}

All seven respondents commented on the importance of authenticity when describing the town, their relationship to it and/or its tourist fascination: for R6 "local and authentic is the key". It is a contentious term when applied to the appeal of cultural tourism industries, and while rooted in both a sense of place, whether temporal or geographic, and a sense of the original or unique linking it to creativity, authenticity is also strongly connected to identity (King, 2011; Robinson et al., 2011). The evolving creation of the self - flexible, mobile and mutable - suggests that negotiating one's identity is a process of adaptability and imagination. This kind of shape-shifting, whether overt or more nuanced, is core to creativity. In its emphasis on the necessity of play for childhood development and adult mental health, psychology in particular recognizes the importance of creativity to identity formation and individuation (van Leeuwen \& Westwood, 2008; Dollinger et al., 2005; Winnicott, 2005). Psychological approaches that position creativity as central to healing and developmental growth, are also related to the attributes of originality and value: the individual's creative engagement with the external world is inevitably unique and facilitates emotional and intellectual wellbeing, arguably elevating their social value (Winnicott, 2005).

For Glăveanu and Tanggaard (2014, p. 15), "identity is constantly performed, and (re)formulated within performance, in the way people react to others, interpret situations, approach them, etc.". It is a continuous process of negotiation between the external and the internal, fundamental to performativity studies. Chryssochoou (2003, p. 225) clarifies this intricate and at times unconscious social dance alluded to by Glăveanu and Tanggaard:

\begin{abstract}
"identity is a particular form of social representation that mediates the relationship between the individual and the social world [...] Its functions are to inscribe the person in the social environment, to communicate peoples' positions and to establish relationships with others (social recognition). Thus identity is a cyclical process constituted by three actions: knowing, claiming and recognizing".
\end{abstract}

She characterizes identity as a container of "motivations and actions" (Chryssochoou, 2003 , p. 227), and rather than an individually sourced and driven concept, argues that it incorporates the individual and the social in a relationship informed by three central questions: “Who am I?', 'Who are they?' and 'What is our relationship?"' (Chryssochoou, 2003, p. 229). In this way Chryssochoou sees identity constituting "the social psychological context within which worldviews are constructed [...] communicated and for which battles are fought" (2003, p. 238). This notion of an evolving internal/external exchange also relates to authenticity and can be considered in the context of traditional creative practices that are 
revived, repurposed and enhanced via technology capable of meeting present-day needs. As Wang (1999) explains, while objective authenticity is associated with traditional, original place-based objects/traditions (as in the heritage architecture and blues museums of and around Clarksdale), constructive authenticity applies to a perception and social construction of authenticity (enfolding events such as the Juke Joint Festival - its music and repurposed/ upscaled juke joint venues). From the Clarksdale respondents' comments, objective and constructive authenticities are relevant concepts. Their remarks - stressing the importance of early blues and its evolution, the town's repurposed historical buildings, and the need to energize new and authentic tourist experiences - resonate with Chryssochoou's individual-social identity formation questions based around the bridging relationship between self and other.

The interviewees, however, emphatically saw the town's identity and their role in revitalization as separate from larger commercial tourist industries. Regarding the introduction of potential tourist attractions and aides for the town, R5 emphatically argued that,

“we don't want to turn ourselves into Disneyland [France]. We don't want to be Branson, Missouri [US] [...] We don't want to be Beale Street [Downtown Memphis,

Tennessee, US] it's always going to be Clarksdale because it's impossible for it not to be".

R2 expressed similar sentiments: "this is not Blues-ville [...] we don't have money [...] we don't have ten million people coming to Graceland [Memphis, Tennessee, US] every year [...] but we're precious and we're recognized". R2 further notes that, "we're a small Southern town that has a lot of culture and you don't want it to be themed [...] then you lose the authenticity of the people and the places". This affirmation of us, them and the reality of economic revival, supports the kind of resilience that comes from an impassioned understanding of how to maintain identity authenticity while competing in the tourist marketplace.

The questioning of "I", "they" and "our relationship", while central to downtown revitalization, is also significant when considering Clarksdale's internal racial - with an $81.8 \%$ African American population - economic, local and newly resident divide (U.S. Census Bureau, 2019). The enthusiasm for revitalization has sometimes proven to be at odds with more established community members (R3, R7). As R7 acknowledges, "only a handful of [downtown] businesses are owned by black business owners", a situation which compels white entrepreneurs to intermittently defend against claims of exploiting blues music and its heritage (King, 2011). While it is important to recognize these tensions and projections, there is not the scope in this study into elaborate on Clarksdale's internal politics; an underlying yet not overtly impeding aspect of its downtown revival strategies (R7). R7 and R4, like R3, also recognize the fragility of community feeling toward the principally blues based tourist momentum, but are optimistic that projects such as the non-profit Coahoma Collective's downtown Travelers Hotel, an artist's cooperative, and the Collective Seed \& Supply Co., a garden and general store in Clarksdale, will positively contribute to bringing artists and the community into a closer relationship.

\section{Facilitating resilience through creative individual and collaborative connections to community}

For Glăveanu and Tanggaard, a connection between the artist, their outputs, and the audiences' acknowledgement of the work is vital. From this perspective, with rare exceptions, 
even the most isolated artist works collaboratively. "Identity is therefore a simultaneously personal and social task and the identity of being a 'creator", they argue (Glăveanu \& Tanggaard, 2014, p. 15), "is certainly a developing project that requires others to see and relate to the person 'as a creator"'. From creativity studies that focus on the individual, to those classifying identity as a mediation between one's inner and outer experiences, Glăveanu and Tanggaard (2014, p. 13) view the subject as "able to co-construct his or her own sense of creative value in communication with others and in relation to societal discourses about what creativity is". This thinking is reflected in Clarksdale's original Downtown Clarksdale Action Plan for Economic Revitalization and its ad hoc progression into 2020, with the emphasis on innovative and creative engagement with the arts, established and emerging artists, environment, audiences, heritage architecture and the economy (Henshall, 2008, 2019; also see R1-R7).

The downtown Delta Avenue venue Ground Zero Blues Club, owned by lawyer and former town mayor Bill Luckett and actor Morgan Freeman, along with Red's Lounge, like other marketed venues on the tourist trail, attracts visitors on a global scale, and, as R1 and R6 acknowledge, offers local artists the chance to regularly perform. R6 comments that collaboration between musicians and blues focused entrepreneurs led to Clarksdale currently being the only town in the Delta to have blues performed every night of the week, even classifying it as the "number one city for music" apart from Nashville, Tennessee, US. R1 comments that "you're offering local guys opportunities to perform" in a climate of tough competition from neighboring Memphis with many artists working gratis to appear in Beale Street. R5 makes mention of the creative locals who leave and return with added knowledge, and those further afield attracted to Clarksdale's artistic and heritage potential like Stolle and Henshall.

Ironically the Walton Family Foundation (WFF) philanthropic group, who support nonprofit projects in Clarksdale, was created by the Northwest Arkansas family who founded and still own shares in the super-store Walmart; its opening in 1971 creating significant competition for Clarksdale's retailers (Henshall, 2008, 2019; Friedman, 2017). The WFF, in part, funded a weir and playground in Clarksdale and provided a seeding grant to enable the operation of the Coahoma Collective (R3-R4). To secure this funding, the Collective was obligated to provide community programming, and the real estate for its hotel - formerly the historic railway workers Webster Building (c. 1921) - and the Collective Seed \& Supply Co., were required to be owned by a non-profit (MDAH. HRI Historic District Profile. District Properties, 2020). However, “the artists' co-op is a separate for-profit business" says R4, elaborating on the development of these two downtown buildings that contribute to Clarksdale's arts-driven revitalization:

"The soon-to-be Travelers Hotel on 3rd Street, [now developed] into a 20-room hotel, will be managed by a group of artists and the hotel will eventually be owned by a non-profit called Coahoma Collective [...] [who also own a] generations-old feed-andseed store [c. 1890]. Those same artists that are managing the hotel will live upstairs at the store $[\ldots]$ and that non-profit has sponsored the opening of this building downstairs” (MDAH. HRI Historic District Profile. District Properties, 2020; also see R4).

The artists who now manage the operational hotel gain hands-on business experience and training in retail and hospitality, with three or four days a week to pursue their art practices.

R4 believes that this will encourage the development of a racially, geographically and gender diverse group of artists who "are very service-minded [and] have a deep understanding 
and love for this community". The project is an example of Glăveanu's and Tanggaard's theory in practice, designed to allow practitioners to find their "creative value in communication with others" and potentially contribute to the development of personal and collective identities. Along with Kay (2000), Anwar McHenry (2011) and Reid et al. (2016) from Australian case studies, argue that whether used for economic purposes or self-expression, the arts and arts programs provide not only economic benefits, but opportunities for social interaction, meaning, community identity, regeneration, and for Anwar McHenry, a "sense of place" (2011, p. 245). Local entrepreneurs are also invested in collaboration, interdisciplinarity and, as with the Travelers Hotel project, multitasking: "we're looking outside the box, trying to utilize these things in conjunction with [...] co-op ownership or mentorship or non-profit" (R2).

Prominent downtown street signage listed in the City of Clarksdale (2020) website celebrates homegrown historical celebrities and those who have forged relationships with the city, including musicians William Christopher Handy, Sam Cooke, John Lee Hooker, Ike Turner, Muddy Waters, Robert Johnson, Bessie Smith, athletes, civic leaders, actor Freeman and playwright Williams. These homages offer a sense of collective pride and creative potential (R5). Ben Lewis, the job training program director of the Meraki Roasting Company, an initiative of the non-profit Griot Arts - grantee of the WFF - works the concept of resilience into his barista, coffee roasting, and business career ready program designed to invest in the future of generation Z locals. As the Meraki Roasting Company's (2020) website notes, "Meraki" ("mer-ah'-key") is a Greek word meaning "to put soul, creativity, and part of yourself into your work". Like the Travelers Hotel, Meraki Roasting Company inhabits a repurposed downtown building (c. 1915) and functions as a community meeting and arts venue (MDAH. HRI Historic District Profile. District Properties, 2020).

\section{The significance of place}

As well as the connection between creativity and an evolving sense of identity, the concept of place is a significant element of this relationship. Incorporating a variety of combined arts and retail ventures, $\mathrm{R} 3$ claims that revitalization initiatives aim to build an environment attractive to tourists, improve the quality of life for residents, and restore the city's historic buildings, identifying seventy-seven of an estimated 115 sites that have been completed. Yazoo Pass, a popular downtown café and restaurant for instance, was once the old Woolworth Building (c. 1952) (MDAH. HRI Historic District Profile. District Properties, 2020). "I remember the smell of popcorn [there] [...] when I was four years old", says R5. Rebuilding Clarksdale while maintaining the integrity of its architecture, arts legacy and economic potential, is reflected in the maintenance and investor repurposing, rather than renovation, of the downtown historical buildings catalogued by the Mississippi Department of Archives and History (MDAH. HRI Historic District Profile. District Properties, 2020). These sites dating to 1859, with 1932 cited on the City of Clarksdale (2020) website as the median building period, are still ripe for commercial upgrading with $30 \%$ of 250 downtown buildings still vacant.

Clarksdale established its historic district because of the tax credits available for the restoration. As R2 and R3 explain, these state and federal discounts offset investor refurbishment 
costs, with the state of Mississippi offering 25\%, and the federal government $20 \%$ preservation tax credits. Visiting the now repurposed historical buildings as cafes, stores, hotels, restaurants and juke joints, is a unique experience. The architecture is suggestive of millennial business venues keen on cultivating a rustic ambience, but for R4, while hipsters may strive for this look, "this is just authentic Clarksdale. Nobody put a faux-finish on this building [where the interview took place]". Not only does repurposing historically significant sites have monetary advantages for entrepreneurs and attract tourists looking for an authentic experience, it also potentially contributes to community sustainability, pride in place/heritage and a sense of identity (Lee \& Chhabra, 2015). The endurance of Clarksdale's buildings, monuments to a time of prosperity and political and racial hardship, endure as symbols of resistance and resilience.

Agricultural tourism, as R1 explains, is also popular, with cotton gin owners - a "gin" in this sense is an abbreviation for the "engine" that separates seeds from cotton - allowing tours "during the ginning process [...] harvesting the cotton, baling it up, and just watching it go from the fields to be prepared and ready to go out". The potential for developing an agritourism museum that charts the history of cotton from planting, harvest and dissemination to the mills, is in consideration. Related to this mapping of cotton manufacture, the Meraki Roasting Company building, along with a number of historic downtown sites, was originally designed for cotton "grading, sampling and [...] brokerage" with skylights installed to allow enough "natural light to examine the cotton samples for grading" according to current owner Evans' original 1929 Sanborn Insurance Map (2020). The town is also working on a civil rights museum focused on local racial justice advocate Aaron Henry's writing and activism says R3, who, along with R2, is quick to also elevate Clarksdale's Williams legacy, celebrated in the annual Tennessee Williams/New Orleans Literary Festival introduced in 1992 (see Hamlin, 2012). Williams who saw his first film in Clarksdale's Paramount Theatre, formerly The Marion Theatre (c. 1918), grew up in Clarksdale and is said to have modeled the character of Blanche DuBois in his Pulitzer Prize winning play Streetcar Named Desire (1947) after town founder John Clark's daughter Blanche Cutrer (R2-R3). These and other place-based interests for tourism and potential artistic, academic and historical appreciation are sandwiched between the dominant histories, practices and promotion of blues music.

The significance of place, mentioned in Anwar McHenry's research on the value of arts for rural communities, contributes to the resilience of individual artists. Although culturally and geographically removed from Clarksdale, Drake's (2003, p. 518) interviews with creative metalworkers and digital designers in London (United Kingdom (UK)), Sheffield (South Yorkshire, England, UK) and Birmingham (West Midlands, England (UK)) demonstrate a comparable emphasis on the significance of place to "inspiration", "stimuli" and "aesthetic creativity". In exploring how identity for artists is shaped by physical locations and their historical significance, Drake's (2003, p. 518) data indicates that locality supports artistic practice as "a resource of visual raw materials and stimuli", in the formation of "social and cultural networks", as a source of branding "based on reputation and tradition", and as a way of accessing "communities of creative workers". These four specified areas resonate with the experiences of Clarksdale's artists and entrepreneurs, with the value of place holding local and global appeal. 


\section{Conclusions}

This article has argued that creativity in all its collectivity and interdisciplinary, when combined with a strong sense of community identity and deep-rooted deference to "place" and its legacy, is able to advance social, cultural and economic resilience. Tourist focused initiatives have necessarily been massaged into Clarksdale's need for local, national and global attention, with the ambition of nurturing economic sustainability and incremental resurgence. Henshall sought to harness entrepreneurial energy through his Downtown Clarksdale Action Plan for Economic Revitalization - a proposal based on the potential of a unique blues heritage and the inner creative resources of local, tourist and newly resident stakeholders. The increase in downtown businesses has created employment opportunities and a vision for future investors, with patrons to the celebrated Clarksdale Juke Joint Festival growing from modest beginnings in 2004 to an estimated 7000 in 2018. As noted in the Juke Joint Festival (2020) website, its international reputation provides income and employment for local businesses, contributes to the popularity of blues music now performed each night of the year, and has incentivized the growth of accommodation venues (Stolle, 2019). The "Clarksdale Comeback" though, the Juke Joint Festival site's moniker for the city's growing prosperity, is not entirely based on economic gains.

This paper was researched prior to the full effect of the 2020 coronavirus pandemic. Currently local businesses including blues venues are closed, the Juke Joint Festival with its critical revenue raising has been cancelled, and the community is in lockdown. Instructive for similar inland communities, the test of Clarksdale's future sustainability may depend on the city's capacity to harness its creative energy and passionate identification with historical and contemporary arts culture: qualities that have allowed the community's "creative people" to ease downtown out of past impoverishment. If the core driver of resilience is the ability to meet and adapt to change, or in the case of the coronavirus, unprecedented global upheaval, then Clarksdale's historical "comeback" challenges inspire hope.

\section{Acknowledgements}

Appreciation is extended Trevor Hogan, Raul Sanchez-Urribarri and Melissa Kennedy for contributing valuable feedback to this article. I would also like to express thanks to the interviewees, Henshall and the people of downtown Clarksdale who generously responded to various queries.

\section{Funding}

The author acknowledges that this research was completed with the assistance of a La Trobe University, Melbourne, Australia, Social Research Platform Grant and the La Trobe Humanities Internal Research Grant Scheme. 


\section{References}

Anwar McHenry, J. (2011). Rural empowerment through the arts: the role of the arts in civic and social participation in the Mid West Region of Western Australia. Journal of Rural Studies, 27(3), 245-253. https://doi.org/10.1016/j.jrurstud.2011.03.001

Barron, F. (1955). The disposition towards originality. The Journal of Abnormal and Social Psychology, 51(3), 478-485. https://doi.org/10.1037/h0048073

Beaulieu, L. J. (Ed.). (2019). The Rural South in crisis: challenges for the future. Series: Rural Studies Series. Routledge. https://doi.org/10.4324/9780429314407

Berkes, F., \& Ross, H. (2013). Community resilience: toward an integrated approach. Society and Natural Resources, 26(1), 5-20. https://doi.org/10.1080/08941920.2012.736605

Bryant, Ph. (2016). 2016-2019 State of Mississippi Delta Region Development Plan. https://dra.gov/images/uploads/content_files/Mississippi_State_Plan-DRA_FINAL-2016.pdf

Chryssochoou, X. (2003). Studying identity in social psychology: some thoughts on the definition of identity and its relation to action. Journal of Language and Politics, 2(2), 225-241.

https://doi.org/10.1075/jlp.2.2.03chr

City of Clarksdale. (2020). Clarksdale, Mississippi. https://www.cityofclarksdale.org/

Dollinger, S. J., Clancy Dollinger, S. M., \& Centeno, L. (2005). Identity and creativity. Identity: An International Journal of Theory and Research, 5(4), 315-339. https://doi.org/10.1207/s1532706xid0504_2

Drake, G. (2003). "This place gives me space": place and creativity in the creative industries. Geoforum, 34(4), 511-524. https://doi.org/10.1016/S0016-7185(03)00029-0

Evans, Ch. (2020). Sanborn Insurance Map [unpublished source].

Friedman, A. (2017). This Is not America. Biteback Publishing.

Glăveanu, V. P. (2010). Paradigms in the study of creativity: introducing the perspective of cultural psychology. New Ideas in Psychology, 28(1), 79-93. https://doi.org/10.1016/j.newideapsych.2009.07.007

Glăveanu, V. P., \& Tanggaard, L. (2014). Creativity, identity, and representation: towards a socio-cultural theory of creative identity. New Ideas in Psychology, 34, 12-21.

https://doi.org/10.1016/j.newideapsych.2014.02.002

Hamlin, F. N. (2012). Crossroads at Clarksdale: the black freedom struggle in the Mississippi Delta after World War II. Series: The John Hope Franklin Series in African American History and Culture. W. E. Martin Jr. \& P. Sullivan (Eds.). The University of North Carolina Press. https://doi.org/10.5149/9780807869857_hamlin

Hennessey, B. A., \& Amabile, T. M. (2010). Creativity. Annual Review of Psychology, 61, 569-598. https://doi.org/10.1146/annurev.psych.093008.100416

Henshall, J. C. (2012). Delta Blues at the crossroads: cultural tourism and the economic revitalization of Downtown Clarksdale, Mississippi. Thesis Eleven, 109(1), 29-43. https://doi.org/10.1177/0725513612444559

Henshall, J. C. (2008). Downtown Clarksdale: an action plan for economic revitalization. Essential Economics Pty Ltd.

Henshall, J. C. (2019). Downtown revitalization and Delta Blues in Clarksdale, Mississippi: lessons for small cities and towns. Palgrave Macmillan. https://doi.org/10.1007/978-981-13-2107-8

Jacks, W. (2019). Po' Monkey's: portrait of a Juke Joint. University Press of Mississippi.

Juke Joint Festival. (2020). Juke Joint Festival. https://www.jukejointfestival.com/

Kay, A. (2000). Art and community development: the role the arts have in regenerating communities. Community Development Journal, 35(4), 414-424. https://doi.org/10.1093/cdj/35.4.414 
King, S. A. (2004). Blues tourism in the Mississippi Delta: the functions of Blues Festivals. Popular Music and Society, 27(4), 455-475. https://doi.org/10.1080/0300776042000264667

King, S. A. (2011). I'm feeling the blues right now: blues tourism and the Mississippi Delta. Series: American Made Music Series. D. Evans (General Ed.). University Press of Mississippi.

Landry, Ch. (2008). The creative city: a toolkit for urban innovators. Commedia/Earthscan.

Lee, W., \& Chhabra, D. (2015). Heritage hotels and historic lodging: perspectives on experiential marketing and sustainable culture. Journal of Heritage Tourism, 10(2), 103-110. https://doi.org/10.1080/1743873X.2015.1051211

Leeuwen, van L., \& Westwood, D. (2008). Adult play, psychology and design. Digital Creativity, 19(3), 153-161. https://doi.org/10.1080/14626260802312665

Magis, K. (2010). Community resilience: an indicator of social sustainability. Society and Natural Resources, 23(5), 401-416. https://doi.org/10.1080/08941920903305674

MDAH. HRI Historic District Profile. District Properties. (2020). Properties in Clarksdale Historic District. https://www.apps.mdah.ms.gov/Public/district.aspx?id=204\&view=propList\&y=1057

Meikle, P. A. (2016). Globalization and its effects on agriculture and agribusiness in the Mississippi Delta: a historical overview and prospects for the future. Journal of Rural Social Sciences, 31(2), 130-154.

Meraki Roasting Company. (2020). Meraki roasting company by griot arts. https://merakiroasting.com/

Nardone, J. (2003). Roomful of Blues: Jukejoints and the cultural landscape of the Mississippi Delta. Perspectives in Vernacular Architecture, 9, 166-175.

Pratt, R. (1986). The politics of authenticity in popular music: the case of the Blues. Popular Music and Society, 10(3), 55-78. https://doi.org/10.1080/03007768608591250

Reid, A., Petocz, P., \& Bennett, D. (2016). Is creative work sustainable? understanding identity, motivation, and worth. Australian Journal of Career Development, 25(1), 33-41. https://doi.org/10.1177/1038416216637089

Robinson, P., Heitmann, S., \& Dieke, P. (Eds.). (2011). Research themes for tourism. CABI. https://doi.org/10.1079/9781845936846.0000

Runco, M. A., \& Jaeger, G. J. (2012). The standard definition of creativity. Creativity Research Journal, 24(1), 92-96. https://doi.org/10.1080/10400419.2012.650092

Sawyer, R. K., \& DeZutter, S. (2009). Distributed creativity: how collective creations emerge from collaboration. Psychology of Aesthetics, Creativity, and the Arts, 3(2), 81-92. https://doi.org/10.1037/a0013282

Stein, M. I. (1953). Creativity and culture. The Journal of Psychology, 36(2), 311-322. https://doi.org/10.1080/00223980.1953.9712897

Stolle, R. (2019). Mississippi Juke joint confidential: house parties, hustlers and the blues life. The History Press.

Town Charts. (2019). Clarksdale, Mississippi Economy Data. https://www.towncharts.com/Mississippi/ Economy/Clarksdale-city-MS-Economy-data.html

U.S. Census Bureau. (2019). Quick Facts: Clarksdale City, Mississippi. https://www.census.gov/quickfacts/clarksdalecitymississippi

Wang, N. (1999). Rethinking authenticity in tourism experience. Annals of Tourism Research, 26(2), 349-370. https://doi.org/10.1016/S0160-7383(98)00103-0

Winnicott, D. W. (2005). Playing and reality. Routledge. 